\title{
Land Dispute Settlement Through Mediation In The Regional Land Office In Boyolali Regency
}

\begin{abstract}
Sarsono ${ }^{1}$, Joseph Diko Reinol Panjaitan ${ }^{2}$ and Munsharif Abdul Chalim ${ }^{3}$
Abstrak. This study aims to describe the settlement of land disputes through mediation conducted in Regional Land Office of Boyolali Regency, and the obstacles encountered in settling land disputes through mediation. So, it can provide additional knowledge for anyone who reads it. The problem formulation in this research is how the role of the land office in order to settle the land dispute mediation in the Land Office of Boyolali Regency and what are the constraints of the mediation in land disputes in the Land Office of Boyolali Regency. This research is a legal juridical empirical research or legal sociology research. It it kind of research that analyzes a problem by combining secondary data (legislation) with primary data obtained in the field. The result of this research is that the role of Land Affair Office of Boyolali Regency in the effort of settling land dispute through mediation is as mediator who is responsible for assisting the parties in dispute to produce agreement received by the all parties. The parties assist to end up the dispute, then pour the result of mediation into the Minutes of Mediation. In the event of mediation, when the agreement is reached, the parties are willing to implement the mediation decision. However, if in mediation is not reached agreement, the District Office of Boyolali Regency will invites the parties to process through litigation (court). In the implementation of mediation at the Land Office of Boyolali Regency, there are obstacles, namely: (1) The absence of the parties in dispute, (2) there is no good intentions from each party in dispute, (3) Differences in ability and education among the parties, (4) The role of Land Office of Boyolali Regency is only as mediator, it cannot be as a decision maker/court. Keywords: Settlement Of Land Dispute, Mediation, Land Office.
\end{abstract}

\section{Introduction}

Land is a basic need for every human being. From birth to death, people always need the land. When humans are born, it requires a land for a place to live and a source of life. When humans passed away, the land is a place to bury their bodies. Furthermore, land has economic, social, cultural and ecological dimensions.

Land has a big role in the dynamics of development, in the 1945 Constitution article 33 paragraph 3 mentioned that "Earth and water and natural resources contained therein are controlled by the state and used for the greatest prosperity of the people". That is what is meant by earth is on earth (right to land) then planted on earth (like forestry, plants). The meaning of water is the understanding of deepening, the waters of the ocean and the earth under the water. ${ }^{4}$

Seeing the importance of the land for human life, everyone will always try to own the plot of land and master it with all his might, sometimes even in the wrong way. From this

\footnotetext{
${ }^{1}$ Student of Master Program (S2) of Notaries Faculty of Law, Universitas Islam Sultan Agung email sarsons1987@gmail.com

2 Students of Master of Law, Faculty of Law, Universitas Islam Sultan Agung email dikoreinol@gmail.com

${ }^{3}$ Lecturer of Faculty of Law UNISSULA

${ }^{4}$ A.P Parlindungan 2015 Hak Pengelolaan Menurut Sistem UUPA (Act of Agraria). Mandar Maju Bandung p. 3.
} 
issue, it can lead to a land dispute in the community.

Land disputes are an ever-present problem from time to time in tandem with the rapid growth of the population, the development of construction, and the widespread access of various parties to acquire land as the basic capital in various interests.

All issues regarding land disputes require a complete solution. There are various ways of completion paths that can be taken to resolve the land dispute. In addition to dispute resolution through courts/litigation, within the national legal system it is well known that dispute resolution through non-judicial institutions is provided for in Law No. 30/1999 on Arbitration and Alternative Dispute Settlement.

One alternative solution to land disputes is through mediation efforts. Mediation as an alternative dispute resolution offers an appropriate dispute resolution way. Since the process is relatively simple, the time is short and the cost can be reduced. The settlement of disputes through mediation in land affairs should often be done by the Land Office, but it has not been well known by the public. This is due to a narrow understanding of the dispute resolution itself, and the lack of confidence in the effectiveness of the implementation of the mediation verdict.

With regard to land law disputes, dispute settlement through mediation is possible and relevant. This is because mediation provides to parties to a dispute an effort to determine the outcome in accordance with the collective agreement without coercion which is the desire for every society.

Based on the above description, the problem formulation in this study are as follows: what is the role of the Land Office of Boyolali Regency in solving the land dispute in mediation stage? What are the constraints to the implementation of mediation in land disputes at the Land Office of Boyolali Regency?

\section{Research Methods}

In this research, the author used a method of sociological juridical approach. According to F.X. Adji Samekto, Social legal studies conceptualize law as the norm and simultaneously as reality. ${ }^{5}$ Research specification used was descriptive analysis, that is describing problem then analyze the existing problems through data collected, processed, and arranged based on theories used. This research was expected to obtain a clear, detailed, and systematic description by analyzing data to solve the problems in accordance with applicable law.

\section{Discussion}

\subsection{Definition of Land Dispute, Land Conflict and Land Case}

\subsubsection{Land Dispute}

In the law study, it can be argued that the dispute is a matter between two or more persons in which both argue on a particular object. This happens because of misunderstandings or differences of opinion or perception between the two which then

\footnotetext{
${ }^{5}$ Anis Mashdurohatun, Redyanto Sidji, Gunarto and Mahmutarom, Factors Causing Banking Cyber Crime in Indonesian, International Journal of Economic Research, Volume 14 Number 15 2017, p.295.
} 
gives rise to legal consequences for both. ${ }^{6}$

Based on the Regulation of the Minister of Agrarian and Spatial/Head of National Land Agency No. 11 Of 2016 on the Settlement of Land Dispute which states that land disputes are land claim between persons, legal entities or institutions that have no socio-political impact.

Land disputes may be administrative disputes, civil disputes, criminal disputes related to ownership, transactions, registration, underwriting, utilization, tenure and ulayat rights disputes. A land dispute is certainly not one subject, but more than one, whether it is between individuals, groups, organizations, even large institutions such as State Owned Enterprises (BUMN) or the state. The legal status between the subject of the dispute and the land subject to the dispute may be the owner, the holder of the mortgage, the buyer, the assignee, the tenant, the manager, the tiller and so forth. ${ }^{7}$

\subsubsection{Land Conflict}

Conflict means opposition or dispute between people, groups, or organizations against an object of concern. Likewise Winardi confronts the conflict between individuals or groups having the same relationship or interest in an object of ownership that creates legal consequences from one another. ${ }^{8}$

According to the Regulation of the Minister of Agriculture and Spatial / Head of the National Land Agency No. 11 of 2016 on the Settlement of Land Disputes states that land conflicts are land disputes between individuals, groups, organizations, legal entities or institutions that have a tendency or have a wide impact. This broad impacting emphasis distinguishes the definition of land disputes with land conflicts.

\subsubsection{Land Case}

Regulation of the Minister of Agrarian Affairs and Spatial/Head of National Land Agency No. 11 of 2016 concerning Settlement of Land Cases states that land affairs are land disputes whose settlement is carried out by the judicial decisions that are still requested for handling disputes in National Land Agency of the Republic of Indonesia.

\subsection{Settlement of Land Dispute}

Act No. 30 Of 1999 Concerning Arbitrate and Alternative Dispute Resolution Article 6 paragraph (1) reads: "Disputes or differences of civil opinion may be settled by the parties through an alternative dispute resolution based on good faith to the exclusion of a litigation settlement at the District Court".

Rachmadi Usman mentioned that in addition to court (litigation), dispute settlement can also be settled out of court (non-litigation), commonly called Alternative Dispute Resolution (ADR) or Alternative Dispute Settlement. ${ }^{9}$

Based on the above matters, the settlement of the dispute is done in two ways, namely:

- Litigation is settlement of disputes between the parties conducted in court.

\footnotetext{
${ }^{6}$ Bernhard Limbong 2012. Konflik Pertanahan Margaretha Pustaka Jakarta p. 48.

7 Ibid. p. 49.

${ }^{8}$ Ibid. p. 50.

${ }^{9}$ Rachmadi Usman.2012. Mediasi di Pengadilan.Sinar Grafika:Jakarta p. 8.
} 
- Non Litigation is an out-of-court dispute settlement commonly referred to as Alternative Dispute Resolution (ADR) or Alternative Dispute Settlement Alternative Dispute Resolution (ADR) is often defined as: alternative to litigation and alternative to adjudication ${ }^{10}$. In terms of alternative to litigation, all non-court dispute resolution mechanisms, including arbitration, are part of the ADR. And the notion of ADR as an alternative to adjudication may include consensual or cooperative dispute resolution mechanisms such as negotiation, mediation, and consensus. ${ }^{11}$

\subsection{Overview of Mediation}

\subsubsection{Understanding Mediation}

The word mediation comes from English "mediation", which means dispute resolution involving a third-party mediator or dispute settlement mediator.

As an alternative dispute resolution method, mediation has the characteristics of short, structured, task-oriented time, and is a way of intervention involving active participation of stakeholders. The success of the mediation is determined by the goodwill of both parties to jointly find an agreed solution.

The notion of mediation contains elements as follows:

- Mediation is a process of dispute settlement based on negotiation.

- The mediator is involved and accepted by the parties to the dispute in the negotiations.

- The mediator is in charge of assisting the parties to the dispute to seek settlement.

- The mediator has no authority to make decisions during the negotiations.

- The purpose of mediation is to make or produce an acceptable agreement to the parties to the dispute to end the dispute. ${ }^{12}$

From these points, mediation can be interpreted as a process of dispute settlement based on negotiations to make or produce acceptable agreements between mediated parties by a designated neutral mediator who is directly involved in the negotiations, in which the mediator is tasked with assisting the parties to resolve disputes and is not authorized to make decisions during the negotiations.

Given the main purpose of mediation is to solve a problem, not merely a norm or create order only, then the implementation of mediation must be based on general principles, namely:

- Voluntary

Here the parties have a free will to do legal action against the object of the dispute, which is meant in the future there will not arise any objections to the agreement which has been taken in the settlement of the dispute.

- Independent and impartial

In the process as well as the outcome of a mediated settlement must be free from the

10 Sujud Margono.2004. ADR dan Arbitrase "Proses Pelembagaan dan Aspek Hukum".Ghalia Indonesia: Jakarta p. 36.

${ }^{11}$ Ibid P. 35.

${ }^{12}$ Sujud Margono op.cit p. 59. 
Volume 5 Issue 2, June 2018

influence of both the parties themselves and the mediator. In the mediation process a mediator must be neutral.

- Interpersonal Personal Relations

Relationships between parties can be kept good even though the dispute has been completed.

Mediator is the person/official appointed from the ranks of the National Land Agency of the Republic of Indonesia agreed by the parties to the dispute to resolve the issue.

\subsubsection{Stages of Mediation Process}

Risk and Westbrook in a book written by Sujud Margono divide the mediation process into 5 (five) stages as follows: ${ }^{13}$

- Agree to take the mediation process.

- Understand the problems.

- Generate problem-solving options.

- Achieve agreement.

- Implement agreement.

Kovach divides the mediation process in 9 (nine) stages as follows: ${ }^{14}$

- Setup or initial setting.

- Introduction or opening by the mediator.

- Statement of opening by the parties.

- Information gathering.

- Identify problems, agenda setting, and cases.

- Generating troubleshooting options.

- Bargaining.

- Agreement.

- Closure.

\subsection{The Role of Land Affairs Office of Boyolali Regency in Land Dispute Settlement through Mediation}

The role of the Land Affairs Office of Boyolali Regency in the effort to settle land disputes through mediation is as mediator who is responsible to assist the parties to the dispute to produce agreement received by the parties to dispute to end the dispute, which then pour the result of mediation title into Minutes Mediation. If the agreement is reached in mediation, both parties with good faith implement the mediation decision. However, if the agreement is not reached in mediation stage, the District Court will invite the parties to the dispute to process through litigation (court).

From the research conducted at the Land Office of Boyolali Regency obtained data that during 2015 to July 2016 many complaints of land disputes submitted to the Land Office of Boyolali Regency to get dispute resolution encountered. In order to resolve land disputes, the Boyolali District Land Office provides input to the disputing parties to pursue mediation

13 Ibid p. 63.
14 Ibid p. 63. 
as a step to resolve land disputes. Furthermore, when the mediation stage does not produce new results, the dispute settlement proceeds to the litigation path.

The Dispute Data Settlement by Land Office of Boyolali Regency Of 2015 to July 2016

\begin{tabular}{|l|l|c|c|}
\hline No & Sub-District & Report & Mediation \\
\hline 1 & Selo & - & - \\
\hline 2 & Cepogo & 2 & 2 \\
\hline 3 & Ampel & 4 & 1 \\
\hline 4 & Musuk & 2 & 2 \\
\hline 5 & Boyolali & 4 & 3 \\
\hline 6 & Mojosongo & 7 & 5 \\
\hline 7 & Teras & 1 & 1 \\
\hline 8 & Sawit & - & - \\
\hline 9 & Banyudono & - & - \\
\hline 10 & Sambi & 7 & 2 \\
\hline 11 & Ngemplak & 1 & 6 \\
\hline 12 & Nogosari & 2 & - \\
\hline 13 & Simo & 1 & 2 \\
\hline 14 & Karanggede & - & - \\
\hline 15 & Klego & 2 & - \\
\hline 16 & Andong & - & 1 \\
\hline 17 & Kemusu & - & - \\
\hline 18 & Wonosegoro & - & - \\
\hline 19 & Juwangi & 36 & - \\
\hline & JUMLAH & & 25 \\
\hline & & 7 & \\
\hline
\end{tabular}

Based on the above data, many problems concerning land disputes are faced by various communities in Boyolali Regency. Handling through mediation is often taken to get the solution of the problems encountered.

\subsection{Constraints Faced In the Implementation of Land Dispute Mediation at Land Office of Boyolali Regency}

In the implementation of land dispute settlement through mediation at the Land Office of Boyolali Regency is not as easy as we imagined. There are various things that become obstacles in a mediation process. These constraints include:

- The absence of the parties to the dispute.

One of the initial obstacles is the absence of the disputing parties to fulfill the invitation of the Land Office of Boyolali Regency to mediate. If any party is not present to meet the invitation, then the mediation process cannot be implemented, because in the mediation there must be both parties to the dispute.

- There is no goodwill from both party in dispute.

The key to the success of land dispute resolution efforts through mediation is the goodwill of both parties in dispute to resolve the issue well. The absence of good faith from both parties can be a form of mutual insistence and an emotional attitude in 
maintaining the interests of each.

- Differences in ability and education among the parties

People who face land disputes in Boyolali Regency, come from various backgrounds, both from educational background, age and various livelihoods. This is quite difficult for mediation, because sometimes there are parties who have weaknesses in the age of old or low education so unable to convey a clear explanation to defend what should be his right. So often used by the stronger ability to take the opportunity in a narrow to strengthen the position and win their interests.

- The role of Land Office as mediator cannot be as decision maker/court. Regulation of the Minister of Agrarian Affairs and Spatial/Head of National Land Agency No. 11 Of 2016 concerning Settlement of Land Cases states that the mediator's understanding is the party assisting the parties in the negotiation process to find various possibilities of dispute resolution or conflict without using the means of disconnecting or enforcing a settlement.

\section{Closing}

\subsection{Conclution}

Based on the descriptions in the previous chapters and associated with the problems that have been raised and has been conducted research and discussion, the authors can draw a conclusion as follows:

- The role of the Land Affairs Office of Boyolali Regency in the effort to settle the land dispute through mediation is as mediator who is responsible for assisting the parties in dispute to produce agreement. They encourage to end up the dispute. In the case that the agreement is reached in mediation, the parties in dispute with good faith to implement the mediation decision. However, if the mediation is failed, the District Court will invite both parties to settle the dispute through litigation (court).

- Land Affairs Office of Boyolali Regency in resolving land disputes through mediation, experiencing obstacles or obstacles that undergo the process of mediation, namely:

- The absence of the parties to the dispute.

- There is no goodwill from both party in dispute.

- Differences in ability and education among the parties.

- The role of the Land Office of Boyolali Regency is only as mediator cannot be as a decision maker/court.

\subsection{Suggestions}

- Land Office of Boyolali Regency should further improve the quality of human resources, in this case the officials handling cases through mediation in order to be able to provide the best performance as a mediator, so that later can overcome various obstacles that accompany the process of land dispute resolution process through mediation. In improving the quality of human resources, training can be conducted for relevant officials directly related to land dispute resolution efforts through mediation, by 
providing additional materials from experts or sharing experiences with other experienced officials.

- Land Affairs Office of Boyolali Regency to conduct a better socialization to their existence as an institution that can serve as public servants, able to seek alternative land dispute settlement through mediation to the general public, especially socialization through social media. In this case, the socialization can be the number of mediations that have successfully resolved land disputes to all types of land disputes that have the potential to be solved through mediation, and other materials related to land dispute resolution efforts. Thus, the community is more familiar with the alternative solution. Hence, it becomes one of the solutions for the community in the settlement of land disputes as well as to reduce the dispute resolution through the litigation path.

\section{References}

[1] A.P Parlindungan 2015 Hak Pengelolaan Menurut Sistem UUPA (Act of Agraria). Mandar Maju Bandung.

[2] Anis Mashdurohatun, Redyanto Sidji, Gunarto and Mahmutarom, Factors Causing Banking Cyber Crime in Indonesian, International Journal of Economic Research, Volume 14 Number 152017

[3] Bernhard Limbong 2012. Konflik Pertanahan Margaretha Pustaka Jakarta.

[4] Rachmadi Usman 2012 Mediasi di Pengadilan Sinar Grafika Jakarta.

[5] Sujud Margono 2004 ADR dan Arbitrase "Proses Pelembagaan dan Aspek Hukum" Ghalia Indonesia Jakarta.

[6] National Land Agency No. 11 Of 2016 concerning Settlement of Land Cases

[7] Act No. 30 Of 1999 Concerning Arbitrate and Alternative Dispute Resolution 